\title{
Taking liberties with democracy? On the origins, meaning and implications of the Irish water wars
}

\author{
Rory Hearne $^{\mathrm{a}}$, Mark Boyle ${ }^{\mathrm{b}, *}$, Audrey Kobayashi $^{\mathrm{c}}$ \\ a Department of Applied Social Studies, Maynooth University, County Kildare, Ireland \\ ${ }^{\mathrm{b}}$ Heseltine Institute, University of Liverpool, Liverpool, UK

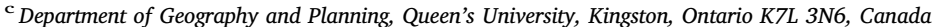

\section{A R T I C L E I N F O}

\section{Keywords:}

Austerity

Protest

Ireland

Sartre

Butler

Scarcity

Public assembly

\begin{abstract}
A B S T R A C T
This paper offers a reading of anti-austerity protests in the Irish Republic, placing under scrutiny in particular the origins, meaning, and implications of the country's water wars. It notes the proclivity of some post-crash antiausterity populisms to fall prey to a politics of retrenchment and exclusion and even to degenerate into nationalist spasms or what Jean Paul Sartre would term fraternity terrorisms. It contributes conceptual novelty to existing human geographical scholarship on protest movements by convening Jean Paul Sartre and Judith Butler in conversation; registering therein the political potential of the fused group, performing popular sovereignty through public assembly. What makes the Irish case fascinating and worthy of scrutiny is the fact that protest never ossified and totalised into an oppressive or regressive form of political populism. Our central argument is that Ireland's water protest movement was effective because it was constituted from outside mainstream politics; from molecular and atomised struggles which scaled and agglomerated into large public assemblies which, whilst ultimately inchoate and indeterminate, signified that popular sovereignty had usurped the centre-right representative regime and challenged the latter's right to custody over democracy.
\end{abstract}

\section{Introduction}

Globalisation, neoliberalism, the global financial crash and austerity have combined to effect a growing dislocation between representative democracy and popular sovereignty. Throughout the advanced capitalist world, there have arisen new Right and Left populisms, and consequential 'earthquake' elections and referenda, which have shocked the body politic. Sage court judges that we now live in the age of the 'left behinds'. Counter-posed to the globalists and hypermobile 'anywheres', the left behinds constitute the 'somewheres', marked by a particular class, education and age profile, anchored in places now rendered redundant by global capital, and abandoned it seems to managed decline and terminal marginality. Populism has mushroomed in communities long overlooked, indeed, sometimes even scorned, by the establishment elite and their representative governments. In a Cri de Coeur, caustic voices declare that the political swamp must be drained and the will of the people restored.

Human geographical scholarship on social movements and protests (Routledge, 2003, 2015; Featherstone, 2012; Halvorsen, 2017; Miller, 2016; Nicholls, 2009) has sought to understand the historical and geographical circumstances in which popular protest arises; the spatiality of protest, its causes and consequences, and; the uneven efficacy of protest. These foci speak intimately to the variegated geographies of political populism currently fermenting in post-crash austerity states, particularly in Europe's periphery. Whilst the Right has shown itself to be particularly adept at claiming the politics of the left behinds (witness Trump, Brexit, Hofer, Wilders, Kurz, Orban and Le Pen), Left populisms too have entered the fray (for example Syriza, Podemos, Costa, Sanderson, Corbyn) (Arampatzi, 2017; Davies and Blanco, 2017; Della Porta, 2015; Featherstone, 2012; Gerbaudo, 2017; Nolan and Featherstone, 2015). And so an urgent research agenda presents itself: what are the progenitors of current populisms and which factors determine whether populisms pivot to the Right or to the Left? Do Right and Left populisms exhibit similar or varying spatialities; if so why and with what consequence? Which populisms are most able to impact and recalibrate the political landscape and why?

This paper places under scrutiny the aetiology, spatiality and efficacy of anti-austerity protests in the Irish Republic, a country with a particularly intense encounter with globalisation, neoliberalism, boom and bust, and savage austerity. Specifically, it offers a reading of the origins, meaning, and implications of the Irish water wars. Ireland is often presented as an exemplar of the virtues of austerity without

\footnotetext{
* Corresponding author.

E-mail address: mark.boyle@liverpool.ac.uk (M. Boyle).
} 
hysteria. Our account challenges the much-propagated myth that notwithstanding years of trenchant, painful austerity, anti-austerity protests have been invisible, ineffectual, and inconsequential. Whilst it is true that the mainstream centre-right representative regime and the established Left (the Labour and Green parties, trade unions, NGOs, charities) offered no meaningful resistance to austerity - indeed were meaningfully complicit in its enforcement - often glossed over in this narrative is that austerity birthed a new generation of civil society, grassroots, place-based activist groups and protest movements. The Irish waters war in particular crashed onto the political scene from 2014, rudely interrupting the hegemonic narrative that the country's austerity programme had been passively if grudgingly accepted by a 'sober' and 'responsible' Irish people, who had in turn been rewarded with an impressive 'Celtic Comeback'.

We develop our argument in three sections. First, we bring conceptual novelty to existing human geographical scholarship on social movements and post-crash anti-austerity populisms by convening Jean Paul Sartre and Judith Butler in conversation and registering the political potential of the fused group, performing popular sovereignty through public assembly. Second, we introduce Ireland's austerity programme confronting the prevailing myth that the Irish population accepted austerity without popular resistance. Third, with the support of new survey, interview, and participant engagement data and a series of empirical vignettes, we attempt to render intelligible the Irish water wars. Our central thesis is that when set into international relief Ireland's anti-austerity protests were distinctive insofar as their genesis lay in everyday encounters with austerity and atomised and molecular struggles, which scaled, agglomerated, and gathered momentum to become a historical force. In Ireland, a vigorous and dynamic group in fusion took to the streets and at least for a critical period, popular sovereignty usurped representative politics and challenged its custody of democracy.

\section{Sartre, Butler and the intelligibility of the risen people}

The thought of Jean Paul Sartre weighs heavily in the scholarship of Judith Butler, yet the project of interrogating the intellectual complementarities and dissonances between them remains in its infancy. We attempt the more modest task of bringing into conversation Sartre's Critique of Dialectical Reason and Butler's Notes Toward a Performative Theory of Assembly, in the belief that in these volumes Sartre and Butler yield critical insights into moments when representative democracy and popular sovereignty dislocate, beginning with molecular struggles rooted in privations encountered in everyday life, not least in times of austerity. These insights inform a theory of social movement, placing front and centre the swarming and coalescing of atomised protests into a consequential political force. We focus particularly upon the nexus of scarcity, alienation, and anarchic protest in the Critique, and precarity, public assembly, and popular sovereignty in Notes.

The theme of human freedom in situation connects Sartre's philosophical, literary, and political writings, and his activism (Sartre, 1943). But he understood and realized this project in different ways as he drifted famously from existentialism (especially Being and Nothingness, 1943 to existential Marxism (rising to a crescendo with his 1960 Critique of Dialectical Reason) and finally to a semi-messianic anarchism of sorts (in his controversial interviews with Benny Levy just before his death published in 1980 as Hope Now) (Sartre and Levy, 1995). Sartre came to recognize the weight of historical and social processes in alienating human beings and delimiting the situations where they can act freely and authentically. Steadily, he became aware of the need for collective action and group praxis in support of human liberation becoming at some stage a dogmatic Marxist. Always, however, he remained suspicious of 'fraternity terrorism' or the ossification of liberation movements themselves into crippling and oppressive bureaucracies.

In the Critique, Sartre set himself the task of rescuing Marxism from its degradation at the hands of Bolsheviks and under the tyrannical reign of Stalin, a revolutionary strand he construed as a historical perversion. Rejecting deterministic historical teleology, he sought to write an anthropology of the authentic Marxist movements which would overturn capitalism and colonialism. Existentialism was positioned now as a parasitical and subordinate philosophy with value only insofar as it could serve a new western Marxist tradition. Sartre was determined to establish the basis for totalisation without a totaliser. But his tortuous linguistic repertoire and schematic formulations (articulated with infuriating fluency) failed to unlock the secrets of history. Instead of totalisation, Sartre could see only a restless and circular dialectic. He aborted his project, leaving only incomplete manuscripts. But what he concluded as a failed intellectual project has turned out to be a work of great originality and relevance (Boyle, 2005; Boyle and Kobayashi, 2011, 2015; Kobayashi and Boyle, 2014).

Sartre set out what he termed a theory of practical ensembles (Sartre, 1976). In many ways this theory hinges on his notoriously pessimistic proclivity to construe interpersonal relations as essentially predatory and violent. Encountering the facticity of the world, I allow myself to fall prey to the 'look' of others, serve as a being for others, lapse into bad faith and default to inauthentic modes of being. Unpacking this facticity, and notwithstanding his Marxism, he turns to scarcity as a pivotal concept: tracking a path through Marx, Malthus, and Smith, scarcity becomes the core progenitor of history. Occasionally, he appears to imply that scarcity is a species condition and has ontological status; all human history is mediated by struggle against absolute scarcity. But of course he recognises that scarcity is historically produced and relative; societies figure distributive mechanisms to allocate resources, creating contingent scarcities, or what Sartre refers to as milieu of scarcity. Human relations remain essentially predatory and violent but now we understand why: crudely put, others constitute a threat to my capacity to access limited resources and even to my survival; more subtly, a Hobbesian bellicosity perpetually sabotages sociality.

For Sartre, in any milieu of contingent scarcity there exists a dialectic between passivity and protest. In the passive moment the weight of scarcity generates mistrust, suspicion, atomisation, a plurality of solitudes. Scarcity overwhelms sociality. A group exists, but only in a practico-inert state as its members line up in series to accept their rationed resources. Defaulting to type by using a seemingly banal example to make a profound point, Sartre cites the group dynamic inherent in a large crowd of people queuing to board a busy bus, perhaps on a wet winter morning, to capture the dehumanising effects of scarcity and its insidious undercutting of interpersonal collegiality. In the protest moment, there emerges a realisation, however fleeting, that solidarity, mutuality, and reciprocity present best hopes for survival. To escape seriality, individual projects conjoin into a 'group in fusion' filled with a sense of empowerment and hope. Vulnerability is converted to agency, and sociality overwhelms scarcity. Citing the street marches which coalesced to end with the storming of the Bastille, Sartre reveals the social and spatial imaginary underpinning his understanding of group fusion in action.

Sartre sought to understand how fused groups might totalise to create revolutionary movements with historical purpose. He invoked the concept of the third party, to account for the ways in which a 'third' serves as a point of confluence for two tributaries of protest, uniting and re-routing them into a larger watercourse. As thirds pile upon thirds, a wider alluvial fan of opposition gives way to a single powerful river of protest. Third parties work only when they frame their own projects as congruent with projects being pursued by others and synthesise this multiplicity into a derivative, but entirely novel, historical current. Because the process is empirical and perpetually emergent, one can never tell in which direction and to what ends protest may lead. On this basis, Sartre found himself unable to conclude that history had a purpose and was forced to concede there could be only totalising (a process) and never totalisation (an end). 
Whilst investing in the emancipatory potential of the group-in-fusion, Sartre was acutely aware of its fragility. Scarcity weighs on humans so that they constantly undercut moments of solidarity and often progressive liberation movements abort, petrify, or dissolve without a lasting legacy. But grappling always with the shadow of Stalin, Sartre found himself ironically more suspicious of the growth and structuring of those fused groups which did survive and prosper. In spite of himself, he became consumed with the bourgeoisie claim that all revolution is ordained to end in totalitarianism. To sustain themselves, fraternities need to institutionalise, but by institutionalising they risk establishing new types of oppression. Without assuming any particular sequence, Sartre imagined groups-in-fusion fossilising, ossifying, into fraternities, statutory groups, organisations, institutions, and social classes: in a circular dialectic as one oppressive socio-political formation was overturned only to be replaced, after a brief period of agency and empowerment, with a different but equally oppressive alternative.

The Critique remained unfinished and Volume II only partially written (Sartre, 1991). Sartre appeared to concede that only small nomadic guerrilla groups waging endless attacks against hegemonic serialities offered hope. This conclusion has long frustrated scholar-activists who have sought guidance and inspiration to find that only perpetual struggle to be a laudable end in itself; hope that a better destination might be reached was futile and dangerous.

Whilst scarcity does not figure prominently in the work of Judith Butler, the cognate concept of precarity certainly does (Butler, 2004, 2009; Butler and Athanasiou, 2013). Precarity 'designates that politically induced condition in which certain populations suffer from failing social and economic networks of support more than others and become differentially exposed to injury, violence, and death. Precarity is thus the differential distribution of precariousness' (Butler, 2015: 33). In neoliberal times, precarity has become a defining feature of human existence but burdens disproportionately vulnerable social groups (by spatial location, class, age, gender, sexuality, disability, etc). But it is also a critical condition that enables a disparate variety of subjugated peoples to galvanise into a coherent protest movement. The quest for liveable (more-than-bearable) lives is the common claim of these groups. The essential political project is to maximise human flourishing by creating social conditions which sustain viable lives in conditions of endemic precariousness.

In Notes, Butler (2015) considers the complex relationship between democratic regimes and public assemblies (gatherings, demonstrations, protests, occupations, marches). Insofar as they are capable of making a claim to represent the will of the people, public assemblies can present as an existential threat to representative regimes; illogically, consistency of logic mandates democratic societies to protect freedom of assembly, even if it results in revolution and their own demise. But of course they rarely do. A juridical apparatus has emerged to monitor - in reality to constitute - the boundary between civil disobedience and public disorder, the latter often used as grounds to limit the former. But when states lose control of their capacity to classify, regulate, and police civil disobedience, they also lose their ability to control the narrative of popular sovereignty and to sustain their claim to be the legitimate guardian of democracy.

Butler enunciates the qualities of public assemblies in times of precarity, interrogating the capacity of public assemblies to make the verbal and written claim - or 'discursive wager' - that they express the will of the people. These declarations inevitably are spurious; no one can confidently speak on behalf of the people as the very notion 'the people' is conceptually dependent upon specific inclusions and exclusions. The pre-discursive iconographies of public gatherings forge this claim more effectively anyways. Assemblies are plural performativities. Public assemblies 'signify in excess of any particular written or vocalised account of what they are about' (Butler, 2015: 8) and 'the enactment of the people exceeds its representation' (Butler, 2015: 163). What plural performativities signify depends upon context and thus varies over time and space. But Butler references the particular and virulent symbolism of public assembly in this age of neoliberal governmentality. Against the figure of the sovereign, resilient, and entrepreneurial subject, fit for and thriving in a precarious world, corporeal and all-toofragile bodies huddling together in support of each other provide a disruptive reminder that we are a social species, co-dependent, and capable of leading liveable lives only by prioritising mutual care, social solidarity, and reciprocity.

Here Butler provides resources to advance the political potential of the Sartrean group-in-fusion. Insofar as the fused group totalises in and through public assembly - the storming of the Bastille - it is invested with power to signify itself as a manifestation of popular sovereignty. In this era of neoliberal redux, the fused group does more than simply struggle. Its very existence constitutes an existential threat to representative democracy, calling into question the claim that representative politics is popular sovereignty. Perhaps the deepest significance of the group in fusion then is that, through its spatiality, it gains potential to perform popular sovereignty and thereby to discipline representative regimes that take liberties with democracy.

\section{Ireland: Bearing austerity with sober stoicism?}

A frontline casualty of the global financial crash, as the Celtic Tiger economy faltered and against the backdrop of an epic domestic financial and property crisis, beginning in 2008 Irish governments implemented a series of gargantuan bank bailouts and savage austerity budgets (O'Riain, 2014; O'Callaghan et al., 2015). At the behest of the EC, the Irish state guaranteed the liabilities of the country's six largest banks (estimated at $€ 365$ billion) and provided a further $€ 64$ billion to recapitalise these banks and to service obligations to (some unsecured) bondholders. NAMA, the government's newly formed bad bank, mopped up the banks' toxic debts, acquiring loans with an original value of $€ 77$ billion for a reduced (but still inflated) price of over $€ 32$ billion. Saddled with an ailing economy, unmanageable bank guarantees, an alarming debt-to-GDP ratio, and a significant budget deficit, the Irish state found it difficult to borrow on international markets and turned to the Troika (EC/ECB/IMF) for a bailout package for itself (from 2010 to 2013) of up to $€ 78$ billion. Monitored by the Troika's External Programme Compliance Unit (EPCU), these loans came with conditions and structural adjustments that deepened Ireland's domestic austerity regime. In fact, from 2008 to 2015, the Irish Parliament passed eight austerity budgets involving cumulative cuts to public spending and social welfare of $€ 20.5$ billion and tax increases of $€ 11.5$ billion, amounting to almost $20 \%$ of the country's GDP.

It is accurate to say this recovery package was imposed on the Irish state by the Troika. But the Irish state was not a hapless bystander, as the mainstream Irish representative regime firmly also pinned its hopes for recovery on austerity and neoliberalism redux: Celtic Tiger 2.0 (Coulter and Nagle, 2015; Boyle and Wood, 2017). Only by becoming an even more liberalised, entrepreneurial, and competitive entrepôt for global capital would Ireland again prosper. Even the established Left appeared to concede that there was no alternative to Ireland's glocalised development model; the Labour and Green parties actively supported the implementation of austerity measures and Irish Trade Unions (including large unions such as IMPACT, SIPTU, and ICTU), NGOs, and charities opted not to oppose such measures significantly.

Ireland has been held up by the Troika as a poster child of the virtues of bailout and austerity-led recovery. The 'Celtic comeback' has been celebrated with heightened and at times indecent glee (Roche et al., 2017). Certainly, encouraging data can be referenced. The economy grew by $4.5 \%$ in $2014,6.2 \%$ in $2015,5.2 \%$ in $2016,4.7 \%$ in 2017 , and further growth of $4.2 \%$ is expected for 2018 ; the unemployment rate, $15.1 \%$ in 2010 , is projected to be $6.4 \%$ in 2017 and stands at 5.8\% today (September 2018); the Government's Debt/GDP ratio is on a downward trajectory (forecast to be $68 \%$ for 2018); and Ireland's current account is on course towards a balanced 2018 budget. Having swallowed its neoliberal medicine, it is proffered, Ireland is 
firmly on the march again. Other recalcitrant and bankrupt EU countries would do well to take note of the Irish recipe for success.

But a number of critical questions remain unanswered. Austerity works according to what metrics? For whom? At what cost? Recovery because of what? (Kinsella, 2012; Kitchin et al., 2012; McCabe, 2013; Kearns et al., 2014; Mercille and Murphy, 2015; O'Connor and Staunton, 2015; Regan, 2016). As the welfare of bondholders, bankers, developers, and international investors was being attended to, austerity was inflicting significant pain on Irish citizens, particularly lower income and vulnerable groups (especially unemployed, lone parents, children). Austerity measures included an income levy and increases in income taxes, reductions in public sector pay, a VAT increase, reductions in health care entitlements, social welfare cuts, cuts to state funding for community services in disadvantaged areas, a massive retrenchment in capital infrastructure investment (in particular, social housing), third-level fee increases, a new household charge (flat property tax), privatisation of state assets, and the introduction of domestic water charges. It is hardly surprising that there has been a marked spike in mortgage arrears and defaults, homelessness, youth unemployment, emigration, and suicide (Hearne, 2015).

Given the heavy toll exacted by the Troika partnership recovery model, the complicity of representative government, and the absence of established Left oppositional voices, the apparent invisibility of popular protest in Ireland has been the subject of considerable international and domestic puzzlement (O'Callaghan et al., 2014; O'Connor, 2017; O'Callaghan et al., 2015). Austerity has unfolded it is supposed without provoking a significant push back let alone a political rupture. Although a gross over-simplification, some commentators have speculated upon the historical importance of the Catholic Church and the lingering persistence of cultural conservatism, stoicism, and penance. The Irish people, it is said, 'partied too hard' during the hedonistic days of the Celtic Tiger. Interior guilt was now creating a willing audience for messages of sobriety and prudence. The Irish were deemed to have expressed their anger in the 2011 general election with the collapse of the centre-right Fianna Fáil party, and the election of Ireland's other centre-right party, Fine Gael, in a coalition with the third largest party, the centre-left Labour Party. Substituting one centre-right party for another was the extent of the retribution sought by the Irish electorate.

The former Minister for Finance, Brian Lenihan, commented in April 2009 that other European countries were 'amazed' at the Irish budgetary adjustments and that there would be 'riots' if these adjustments were visited upon other countries. Rewarded for 'responsible crisis management' with an appearance on the cover of Time Magazine in October 2012, Irish Taoiseach, Enda Kenny, boasted that there had been no large-scale demonstrations in Ireland because '[Irish] people understand that you have to do difficult things to sort out our own public finances'. Ireland has been described as an 'extraordinarily moderate and passive society' comprising a 'passive' and 'demobilised' citizenry. Its response to austerity has been 'not much more than a long collective whinge'. Contrasting the actions of Irish workers and citizens with those in Iceland, Portugal, the UK, Italy, Spain, and Greece, Fraser et al. (2013: 41) conclude 'Ireland sticks out because its bailout and the associated austerity has not been met with significant sustained resistance from trade unions and civil society.... It is almost as if the general populace has given their passive consent to austerity'.

But what is often ignored in the story of Irish acquiescence is that in the absence of leadership from within representative government and from the established Left, community activists, grass-roots advocacy groups, small trade unions, and more radical political parties, have given birth to an anti-austerity politics organised largely outside of the mainstream political regime and, especially at a local level, based on everyday encounters with privation and precarity (Hearne, 2014).

In a plethora of disparate demonstrations, tens of thousands of pensioners, students, and community organisations protested welfare cuts and fee increases in 2008 and 2009. Small Irish 'Occupy' protests were held in 2011, while the Dublin Council of Trade Unions organized a number of anti-austerity protests. Disadvantaged inner city communities under attack from devastating cuts to community development funding animated the protests with symbolic artistic creations such as the 'Austerity Kills' street theatre, which operated under the banner of 'the Spectacle of Defiance'. The anti-bank debt 'Ballyhea Says No to Bondholder Bailout' weekly protests, started in 2011 in a small rural town in County Cork and subsequently inspired other 'Says No' groups across the country. Local hospital action groups, disability groups, youth groups (e.g. 'We're Not Leaving'), lone parent families, parents and teachers contested reductions in special needs assistants, and environmentalists resisted plans to privatise national forests. December 2011 saw the 'Campaign against the Household and Water Taxes' launched by a collection of such groups. The campaign had initial success with $50 \%$ of eligible households boycotting the charge, but the Inland Revenue received powers to withdraw the charge from welfare payments and wages, thus nullifying the campaign. The Anglo 'Not Our Debt Campaign' also gained momentum in 2012 and early 2013 as public opposition grew to the annual repayment of $€ 3.1 \mathrm{bn}$ of the $€ 30 \mathrm{bn}$ debt due in bondholders in lieu of the especially reckless actions of the Anglo-Irish Bank.

The bailout agreement of 2010 between the Troika and the Irish government included the introduction of household water charges and the establishment of a new public utility, Irish Water. Irish Water was to assume responsibility for all water and waste-water provision and disposal, hitherto managed by local authorities and provided free at the point of supply. Water charges and an associated household water metering programme were implemented from January 2014. The projected average charge was $€ 500$ per household and $€ 1200$ for a household with two adults and three children.

Within this context, the Irish water protest movement entered the political stage as a focal point for anti-austerity opposition. Undoubtedly the largest, broadest, and most sustained social movement in Ireland since independence in 1921, the historical, social, cultural, and political novelty and significance of this movement cannot be overstated (Hearne, 2015). Coming six years into the austerity programme, at a time when Ireland was exiting the Troika programme and seemingly reaping the benefits of frugality, the water protests profoundly shocked a complacent Irish political mainstream, which had discounted and underestimated the devastating reality of the impacts of austerity and an emerging grassroots rejection of the austerity regime.

\section{Sartre, Butler, and a rendering of the Irish water wars}

Our rendering of the water protest movement makes use of fresh survey, interview, and participant engagement data - presented here as a series of supporting vignettes ${ }^{1}$ (Fig. 1; see also Hearne, 2015). First, we examine the causal status of scarcity in the constitution of 'serialised' or 'inert' groupings on the one hand, and progressive anti-austerity 'groups in fusion' on the other, and argue that austerity produced in Ireland a 'milieu of scarcity' which conspired to work the former into the latter. Second we mobilise the concepts of the group-in-fusion, third parties, and plural performativity to render intelligible the molecular struggles rooted in privations in everyday life which coalesced into a national protest movement. Third, we examine the claim that the water

\footnotetext{
${ }^{1}$ In particular, we make use of a large scale online survey undertaken with water protestors ('the 2014 survey'), a series of email interviews with leading coordinators of the movement and ongoing participant engagement. The online survey was undertaken in December 2014 and generated 2556 responses from citizens who had actively participated in water protests. The email interviews were undertaken in May/June 2017 with twelve co-ordinators of the water movement chosen to reflect the three pillars of the movement - smaller trade unions, community activists and independent politicians. In addition, our analysis is informed by participant engagement as a scholar activist by one of the authors (Hearne) in national and local campaigns, the Right2Change policy process, and media debate.
} 


\begin{tabular}{|c|c|}
\hline 2010 & Bailout Memorandum with EU-MF Troika - water charges and setting up of Irish Water \\
\hline $2013 \mathrm{Dec}$ & $\begin{array}{l}\text { Water Services Bill passed through Dail Eireann to introduce water charges from January } \\
2014 \text { at- avg } € 500 \text { per household, } € 1200 \text { for } 2 \text { adults } \& 3 \text { children }\end{array}$ \\
\hline 2014 Jan & Local community-led protests against water meters in Cork, Dublin, regional towns \\
\hline May & Water charges a major issue in local and European elections \\
\hline Sept & 12 arrested at water meter protest. Right 2 Water 'a citizen's campaign' formed \\
\hline Oct 11 & 100,000 attend Right 2 Water national protest in Dublin \\
\hline Oct 21 & One million (two thirds) of households do not register for Irish Water \\
\hline Nov 1 & 150,000 attend 100 s of local demonstrations \\
\hline Nov & $\begin{array}{l}\text { Plans outlined to cap water charges at } € 160 \text { for a single adult household and } € 260 \text { for all } \\
\text { other households until } 2018 \text {, and to offer a water 'conservation' grant of } € 100 \text { for all } \\
\text { households. }\end{array}$ \\
\hline 2015 Jan & 30,000 attend 'Says No' and Community protests in Dublin and 20,000 across country \\
\hline Feb 15 & Five water charge protestors jailed in Dublin \\
\hline Mar 21 & 90,000 attend Right2Water national protest in Dublin \\
\hline May 1 & Right2Water policy conference - First water bill cycle $-57 \%(900,000$ households) do not pay \\
\hline Aug 29 & 100,000 attend Right2Water national protest in Dublin - Right2Change launched \\
\hline Oct-Dec & Right2Change policy principles presented to 20 local meetings across country ( 1,500 attend) \\
\hline 2016 & Third water billing cycle- $61 \%$ of households paid some of their bill \\
\hline Feb & 80,000 attend Right2Water/Right2Change national protest in Dublin \\
\hline Feb & $\begin{array}{l}\text { General election sees } 36 \text { candidates supporting Right2Change elected - majority of TDs } \\
\text { elected on opposition to water charges }\end{array}$ \\
\hline July & Domestic water charges suspended until March 2017 \\
\hline Sept & $\begin{array}{l}50,000 \text { attend Right } 2 \text { Water National protest in Dublin. Cycle } 5 \text { of water bills- } 73 \% \text { do not } \\
\text { pay water bill (just } € 18 \mathrm{~m} \text { of target } € 66 \text { mil collected) }\end{array}$ \\
\hline $2017 \mathrm{Apr}$ & 20,000 attend Right2Water National Protest in Dublin \\
\hline April & $\begin{array}{l}\text { Domestic water charges regime ended, limited metering programme, commitment to hold } \\
\text { referendum to protect public water system as a public good and human right }\end{array}$ \\
\hline Apr/June & $\begin{array}{l}\text { Trial of Jobstown } 7 \text { - protestors charged with illegal detention of Minister Joan Burton at sit- } \\
\text { down water protest in } 2015 \text {. Not guilty verdict returned. }\end{array}$ \\
\hline
\end{tabular}

Fig. 1. Timeline: The Irish water wars.

Source: Authors own

movement was an effective group-in-fusion insofar as it usurped representative politics, but that the political mainstream has weathered the storm and is presiding over a new period of neoliberalism redux.

\subsection{To protest or not? Between seriality and fusion (2008 to 2014)}

The people of Ireland were late in protesting austerity. Indeed, it was only after six years of bank bailouts and welfare retrenchment and after the country had exited the Troika bailout programme that an impactful protest movement emerged. Of course the complicity of the representative regime in the chosen recovery programme and the failure of established Left to challenge this programme explains much of this impasse. We might venture to read formal representative politics in Ireland during this period as little more than a practico-inert deposit from a prior dialectical cycle. A once vibrant group-in-fusion (perhaps dating as far back as the establishment of the state) had degenerated into a fossilised institution unable to apprehend, let alone represent, the vital, lively will of the people. The movement emerged at the conclusion of an earlier, circular, dialectical movement, as a sign perhaps that seriality, especially in its new aggressive guise, would no longer be countenanced.

But even in the absence of leadership from public representatives, why were the Irish citizenry so immobilised? Sartre's theorisation of the interplay of scarcity, passivity, and protest provides one possible explanation. Austerity created in Ireland a historically novel milieu of scarcity in which resources became both rationed and distributed unequally. For a while, communities jostled to minimise their exposure to austerity measures; the public sector was pitted against the private sector, urban communities against rural communities, education budgets against health budgets, indigenes against migrants, employed against the unemployed, the citizenry against bondholders, and developers against disadvantaged communities who were disproportionally ravaged by austerity cuts to community services and social housing budgets. Perhaps, from 2008 to 2014, scarcity overwhelmed sociality and seriality triumphed over fusion. Mutual suspicion and antagonism sabotaged collective empathy and solidarity. So long as the pain of austerity is visited more upon others than upon me, I have little impetus to protest.

But as austerity deepened and introduced intolerable scarcities and precarities, vulnerability transformed into agency and seriality gave way to processes of fusion and collective praxis. The new water charges became a potent austerity measure to galvanise around towards the end of the austerity programme when the cumulative weight of six years of austerity had already been interiorised. The Water Services (No. 2) Bill was then less an object of derision in itself and more a cause around which multiple protest currents could rally; more a third party able to collect a plurality of protests, furnishing them with a common foe. But water proved to be an especially effective third party. Water charges were applied universally and offended the entire populace. Water has traditionally been provided free at the point of supply. Access to water is viewed as a basic human right. And (at least untreated) water is a ubiquitous resource in Ireland. 
Vignette 1 - Resolving an impasse between seriality and fusion? Water as a third party

In the 2014 survey $(n=2556)$, when asked why they were protesting, participants cited objectives immediately related to the imposition of water charges. $58.7 \%$ were concerned with stopping future privatisation of water, $41.3 \%$ viewed access to water as a fundamental human right, and $57.3 \%$ wished to see the abolition of water charges, with only $3.5 \%$ campaigning to reduce water charges. But protestors also harboured deeper grievances: $59.6 \%$ demonstrated because 'austerity had gone too far', and $42.9 \%$ in response to the bank bail-outs There was a palpable sense of injustice that 'ordinary' Irish people have had to pay, through austerity, for the bailing out of bondholders, banks, and developers.Typical responses to an open question probing motives for protesting were:

- 'I will end up in arrears over water. I have no more money to give, I'm on the brink. So rather than sit at home and give out about it, I've decided to support the campaign'.

- 'I'm trying to live on disability for multiple health problems and I live alone so I have nobody to half the bills with'.

- 'It's just unfair and too much. I cannot see at the moment where the money for water is going to come from in my already overstretched budget. As a student and a single parent I find it difficult as it is to make ends meet without having to face this also'.

- 'My mother and her 75-year-old husband are homeless. My sister is $€ 8000$ behind on her mortgage and banks are threatening to repossess her apartment. My 65-year-old father has to use a food bank and cannot afford to heat his house. We've had enough'.

- 'I am a student with no help at all from the government, I'm already working part-time during my Masters to be able to pay my rent and food and I have a loan for my Masters fees, so I don't know how I can pay more than that. And my rent keeps rising. STOP'.

- 'Sick of a tax being added onto everything. We are at two-income family with 3rd-level education, two good jobs, one child, another on the way, and crèche fees higher than our mortgage. It's actually getting to the point it's costing one of us to work, and we are on socalled good wages. Every time we scrimp, they find something else to chip away on us'.

\subsection{Fusion, third parties, and performing popular sovereignty (2014-2016)}

Primitive groups-in-fusion emerged in early 2014 through grassroots, neighbourhood, and community protests actively resisting installation of water meters outside of their homes. The water meter protests initially emerged in, and spread throughout, working class estates in Dublin and Cork, but quickly ignited in other regional towns and villages. Whilst some of the protestors had participated in earlier anti-austerity protests, notably a local Campaign Against Household and Water Tax, few were members of any political party or experienced campaigners. Unencumbered, uninhibited and inventive, these groups devised ingenious schemes to resist water installations. Many were inspired by the 'Ballyhea Says No campaign' and assumed a similar label (such as the 'Dundalk Campaign Against Water, Household Tax and Austerity'; 'Ballyvolane Says No to Water Meters and Privatisation'; 'Cobh Says No to Austerity'; 'Waterford and South Kilkenny Say No to Water Charges'; 'Ballybeg Says No'; and 'Lough Garman Against Austerity').

Vignette 2: The spatiality of primitive fusion in action protesting the installation of water meters

The strategy and action within the water protests contained a strong spatial dimension that explains their origins and success. The installation of domestic meters by private contractors brought austerity visibly and directly into the intimate space of the home. People gathered on the footpaths in the front of homes where meters were being installed, using their bodies as a shield to block access and stop installation. The resistance movement grew across the estates as neighbours were inspired and expressed solidarity with the resisters. An activist from 'Cobh Says No' describes the imaginative spatial tactics communities deployed:'

We ran it like a military operation I suppose, one of our members was very good at strategy and he would say "we are going to do it like this'. He would park his car, first thing in the morning, 6am, by the entrance to the estate. Then he would relay a message of what was coming in [from Irish Water to install meters] - how many vans, cars trucks. He would text the message on to me and normally my role was to be on the car following them (Irish Water) and have someone with me to relay messages about where they were going. Then all the residents had their own Facebook page, so the message would be bounced around so it was an alert system that would allow us to be up and ready to be there when they get in. Then at night we would have street meetings in different areas. We would hold these meetings and there was a real sense of community, of unity, of togetherness. Some residents did want a meter - we had no problem with this. The deal was that if four or five houses (on a street) wanted their meters they got it and there was no falling out. But for the residents that didn't want a meter installed, which were the majority, we protected them and they didn't get one'.

Throughout 2014, the grassroots direct action protests were successful; only $880,000(62 \%)$ of the planned 1.4 million meters were ever installed. As civil disobedience spread across the country and became more animated and confrontational, the Irish Gardai began to make arrests at water meter installation sites. Whilst an effort was made to conflate civil disobedience with public disorder, and to criminalise some assemblies, the movement overall was recognised to be too volatile and powerful for the political mainstream to control or ignore. Furthermore, water protestors engaged in peaceful civil disobedience, all too aware that violence would alienate necessary public support. Still, on 30 September 2014, 12 protesters who had been blocking Irish water workers from accessing a housing estate in North Dublin, were arrested. Five protesters were sentenced in February 2015 for between a month and two months for refusing to give an undertaking to stay $20 \mathrm{~m}$ away from installations. Seven protestors (the 'Jobstown 7') were arrested and charged with illegal detention (using kidnapping legislation) of a government Minister at a 'sit-down' water protest in November 2015. In response to Gardai efforts to enforce orders to install meters, over 200 women silently protested outside Coolock Garda Station in Dublin against Gardai tactics. Wearing pink 'high-viz' jackets and holding candles, they would become known as the 'pink ladies' protestors.

Vignette 3: Performing protest or causing public disorder? When leaving a conferring ceremony at An Cosán in Tallaght Dublin on 15 November 2015, Labour Party TD, Tánaiste and Minister for Social Protection, Joan Burton's unmarked Gardai saloon was surrounded by a large and angry crowd protesting the imposition of water charges, accused in the media of 'banging on the car and smashing the windscreen', 'throwing missiles', and 'discharging a volley of verbal abuse'. A tense twohour stand-off stopped the car from leaving. Burton alleged that Solidarity-People Before Profit TD, Paul Murphy had played an active role in her detention. Eventually, surrounded by over 50 Gardai, the Minister was able to change vehicles and escape the scene.

Subsequently, Gardai arrested 27 protestors and charged, in 
particular, TD Murphy, two South Dublin Councillors and four others (the 'Jobstown 7') with the 'false imprisonment' (kidnapping) of TD Burton and her assistant. After a nine-week trial between April and June 2017, a 'not guilty' jury verdict was returned. A weakness for the prosecution was apparent conflicts between statements made by Gardai and video evidence captured on mobile devices by protestors and circulated widely on social media. Three senior Gardai in particular claimed that TD Murphy had asked the crowd, 'will we let her go or will we keep her all night?' a claim he vehemently denied and which was unsupported by recordings kept by protestors. At the conclusion of the trial, the presiding judge instructed jurors to treat carefully the 'frail memories' of some witnesses.

Irish Taoiseach Leo Varadkar reflected upon the significance of the judge's comments:

'I would be very concerned if it is the case that we would ever have Gardai on a stand in the court giving evidence that is not in line with the facts, that is not in line with the video evidence and I think that there is something there that needs to be looked at both by the Garda Commissioner and senior Garda management. We need to be able to trust that when the Gardai stand up in court and they say something happened that it did happen and it shouldn't conflict with video evidence and if it does then that is a problem.'

Claiming that access to water is a fundamental human right, a national 'Right2Water' campaign formed in September 2014 to harness, coordinate, and scale the Irish water protests. Right2Water was established by five smaller trade unions in alliance with the anti-austerity Left political parties, and 'non-aligned' grassroots community water groups. Whilst a variety of protest tactics were used, encouraged by the effectiveness of direct protests against the installation of meters, Right2Water recognised the symbolic power of people rising to occupy community spaces in defiance of the state. In order to 'scale-up' the power and determination of the local actions and thus show to the political system the strength of the national movement, and to enable a broad participation from across society, Right2Water organised national demonstrations. The first, in Dublin 11 October 2014, attracted 120,000 demonstrators. On November 1st 2014100 separate demonstrations were held in towns and cities across Ireland, involving over 150,000 participants. At least eight national water protest demonstrations were subsequently been held, the last taking place in April 2017, attracting approximately 20,000 demonstrators.

There was nothing inevitable about the scaling of atomised and molecular grass roots protests into a national water protest movement. It took many thousands of communities and individuals at various scales to build local resistance into a quasi-coherent movement with gravitas. While it remained an inchoate movement beyond the control of any single group, the protest came to rely on the coordination of three institutional pillars for direction: locally-based community groups, small 'third party' trade unions, and oppositional anti-austerity Left political parties and independent politicians. Not least because these actors played a central role in the process of thirding a diverse number of protests, populism expressed itself differently in Ireland than elsewhere. An anarchic democratic Left ideology permeated the protests.

Perhaps most important were the five small trade unions that took the decision to break from the ICTU's passive acceptance of austerity, and to embrace anti-austerity currents. Importantly, this third party played a co-ordinating and mediating role, bringing (in the face of a lot of challenges) and keeping together traditionally divided Left political parties, winning the trust of sceptical community activists, and engaging in a public media campaign that communicated the Right2Water campaign as a broad-based, inclusive unifier. They organised in a way that could involve and mobilise, not just the 'usual suspects of left-wing activists', nor be restricted to those willing and able to resist meter installation, but to the broader public exhausted with the austerity regime. Furthermore, they provided an important progressive left populist framing of the anti-austerity sentiment, articulating an inclusive narrative, uniting all those opposed to austerity in solidarity (public and private workers, poor and middle income, indigenous and migrant etc) against the establishment and wealthy elite.

Insofar as they were able to perform popular sovereignty, indeterminate public assemblies called into question the capacity of the representative regime to serve the popular will. The powerful iconic sight of tens of thousands of protestors occupying the streets of cities, towns, and villages evidently shocked public representatives. As Butler intimates, public assemblies signify even before they articulate a claim and, in the Irish case, throngs of bodies, gathering and marching, rapidly captured the attention of the political class, who read it as a signal that they were now seriously out of touch with the people. Through the performativity of national demonstrations, people expressed their desire and hope for change through innovative slogans, hand painted placards, banners and pageantry. The protests were lively, familyfriendly, and hopeful. They sustained the movement, empowered the activists to keep going. At each large national demonstration thousands realised they were not alone, not a small minority, and in this they revealed to themselves and to the political establishment their strength - their collective power (see Plate 1).

\subsection{Popular sovereignty usurps representative democracy? (2016-present)}

Opposition to water charges was a major issue in the 2014 local elections. Anti-austerity left-wing political parties (particularly the leftnationalist Sinn Fein, and the Trotskyist Anti-Austerity Alliance and People Before Profit parties) and independent candidates gained through their support of the water protests. Sinn Fein advocated for the abolition of water charges, but wavered on calling for non-payment, while the radical-left parties openly and actively advocated non-payment and 'mass' boycott of the charges. The establishment centre-right parties of Fianna Fáil and Fine Gael received their lowest combined vote in their history, while the Labour Party saw its support halved from $14 \%$ of the electorate to $7 \%$.

\section{Vignette 4: The representative regime in shock? Why the outcome of the 2016 national election was entirely predicable}

In the 2014 survey $(n=2556), 90.1 \%$ of respondents felt the tactics (direct action in communities, street demonstrations, marches) of the Right2Water movement were effective. $77.6 \%$ stated the most effective way of getting change was through citizen-led protests, followed by voting in elections (52.3\%), local community protests $(40.8 \%)$, and contacting a political representative $(28 \%)$.

Nearly $45 \%$ of respondents said they voted for the main large parties (Fianna Fáil/Fine Gael/Labour) in the 2011 election. Over $70 \%$ of these respondents indicated they planned to change their vote at the next general election. $65 \%$ of all respondents stated that whomever they intended to vote for at the next general election differed from whomever they voted for in 2011. $79.3 \%$ intended to vote for candidates affiliated to or endorsed by the Right2Water campaign. $32 \%$ intended to vote for candidates belonging to the People Before Power/Anti-Austerity Alliance; $27 \%$ for Left independents; $24 \%$ for Sinn Fein; and only $6 \%$ for 'Right' Independents.

Despite the strong support for alternative Left parties, a large proportion of the survey population $(79 \%)$ wanted to see a new political party formed with a platform of anti-austerity, anticorruption, anti-cronyism, radical political reform, and democracy. An overwhelming majority of protestors believed that it was time for a root and branch change in Irish political 
life. When asked what the single most important priority should be for a new party $(n=1327)$, just over $50 \%$ identified equality, followed by fairness (26\%), political reform/democracy (17\%), standing up to Europe (12.7), fairer taxation (10\%), and proper/ decent public services (8.5\%). This result provides strong indication of broad progressive Left sentiment amongst the water movement

In order to assuage protestors, the Fine Gael/Labour government undertook a significant U-turn in November 2014, outlining plans to cap water charges at $€ 160$ per single adult household and $€ 260$ for other households until 2018, and to offer a water 'conservation' grant of $€ 100$ for all households. It also introduced legislation requiring a 'plebiscite' to be held if any future government wished to privatise Irish Water. Still, after the first issuing of water bills in 2015 a majority of households (56\%) had not paid water charges. The highest level of payment was at the third billing cycle in early 2016 when just $61 \%$ of the registered 1.522 million households paid the charges. In late 2016, that level fell back and in the last billing cycle $73 \%$ of those subject to water charges did not pay them.

Buoyed by this 'success', in August 2015 and in advance of the 2016 general election, Right2Water established Right2Change, a political movement which sought ' $a$ fairer, more equal Ireland that benefits all of the people rather than a select few'. Right2Change was based on ten progressive policy principles developed participatorily by community groups, activists, small trade unions, and political independents; its objective to challenge the hegemony of Ireland's two centre-right parties. Right2Change convinced 100 candidates from the anti-austerity Left parties and independents to enter a voting transfer pact. In the February 2016 general election, 19\% of first preference votes and 36 out of 158 seats in the national parliament were won by politicians who had signed up to the Right2Change pact, while a further 99 TDs were elected who had opposed water charges. Sinn Fein increased their support from $9.9 \%$ to $13.8 \%$ and number of seats from 14 to 23 . The Anti-Austerity Alliance/People Before Profit parties increased their presence from 4 to 6 seats. The establishment parties (Fianna Fáil, Fine Gael, and Labour) received their lowest combined support in the history of the state. The Labour Party vote collapsed from $19.4 \%$ to $6.6 \%$ and the party dropped from 37 seats to 7 (see Fig. 2).

After the election, water charges became a central issue in negotiations led by Fine-Gael to form a minority coalition government. Eventually, a historic 'partnership' agreement was reached with Fianna Fáil, on condition that Fine Gael suspend domestic water charges. As a result, charges were suspended for nine months from July 2016 until 31 March 2017. In May 2017, the planned water charges regime was abolished entirely and the majority of households will not now pay for water. The principle that domestic water services should be funded through general taxation and government investment has been accepted, and the metering programme has been stopped. People who paid water charges will get refunds and a referendum enshrining public ownership of water and water services has been promised.

Whilst it has undoubtedly been shaken to the core, there is a sense that representative politics has weathered the storm and resistance has ebbed, diffused, and dissipated. There has emerged no larger third to totalise the water protest movement further, and mechanisms of fusion appear to have reduced significantly. The impetus behind the Right2Change movement has stalled, although a 'Another Ireland is Possible' conference was held in November 2017 by Right2Change, with over 300 water activists registering with the intent of continuing the movement. And as they turn to confront a pressing housing crisis, protestors are finding it difficult to replicate the success of the campaign against water charges, the dramatic Apollo House occupation aside. Ireland's two Right-of-centre political parties may have lost a share of the popular vote but they still remain dominant. Protest has failed to bequeath a new or rejuvenated broad Left political party or formation capable of challenging the hegemony enjoyed by the Right. It might be that, with economic growth and some fiscal relief, anti-establishment politics will run its course and ebb, returning to its 20th century long-run pattern of an ineffectual low.

\section{Conclusion}

This paper is offered as a contribution to existing human geographical scholarship on social movements, and in particular growing literature on anti-austerity protests in Europe's peripheral post-crash recessionary states. It has ventured an interpretation of the origins, meaning and implications of anti-austerity protests in the Irish Republic, focussing specifically upon the country's water wars.

What sense is to be made of the Irish case? To address this question

\begin{tabular}{|c|c|c|c|c|c|}
\hline Election 2007 & TDs & Election 2011 & TDs & Election 2016 & TDs \\
\hline Fianna Fail & 77 & Fine Gael & 76 & Fine Gael & 49 \\
\hline Fine Gael & 51 & Labour & 37 & Fianna Fáil & 44 \\
\hline Labour & 20 & Fianna Fáil & 20 & Sinn Féin & 23 \\
\hline Green Party & 6 & Sinn Féin & 14 & $\begin{array}{l}\text { Independents/Independent } \\
\text { Alliance }\end{array}$ & 19 \\
\hline Independent & 5 & Independents 1 & 14 & Labour & 7 \\
\hline Sinn Féin & 4 & Socialist & 2 & $\begin{array}{c}\text { Anti-Austerity } \\
\text { Alliance/People Before } \\
\text { Profit }\end{array}$ & 6 \\
\hline \multirow[t]{3}{*}{$\begin{array}{l}\text { Progressive } \\
\text { Democrats }\end{array}$} & 2 & $\begin{array}{l}\text { People Before } \\
\text { Profit }\end{array}$ & 2 & Independents4Change & 4 \\
\hline & & $\begin{array}{l}\text { Workers and } \\
\text { Unemployed } \\
\text { Action Party }\end{array}$ & 1 & Social Democrats & 3 \\
\hline & & & & Green & 2 \\
\hline
\end{tabular}

Fig. 2. Election results in Ireland 2007, 2011, 2016 (in bold ruling party or coalition).

Source: CSO, Ireland 


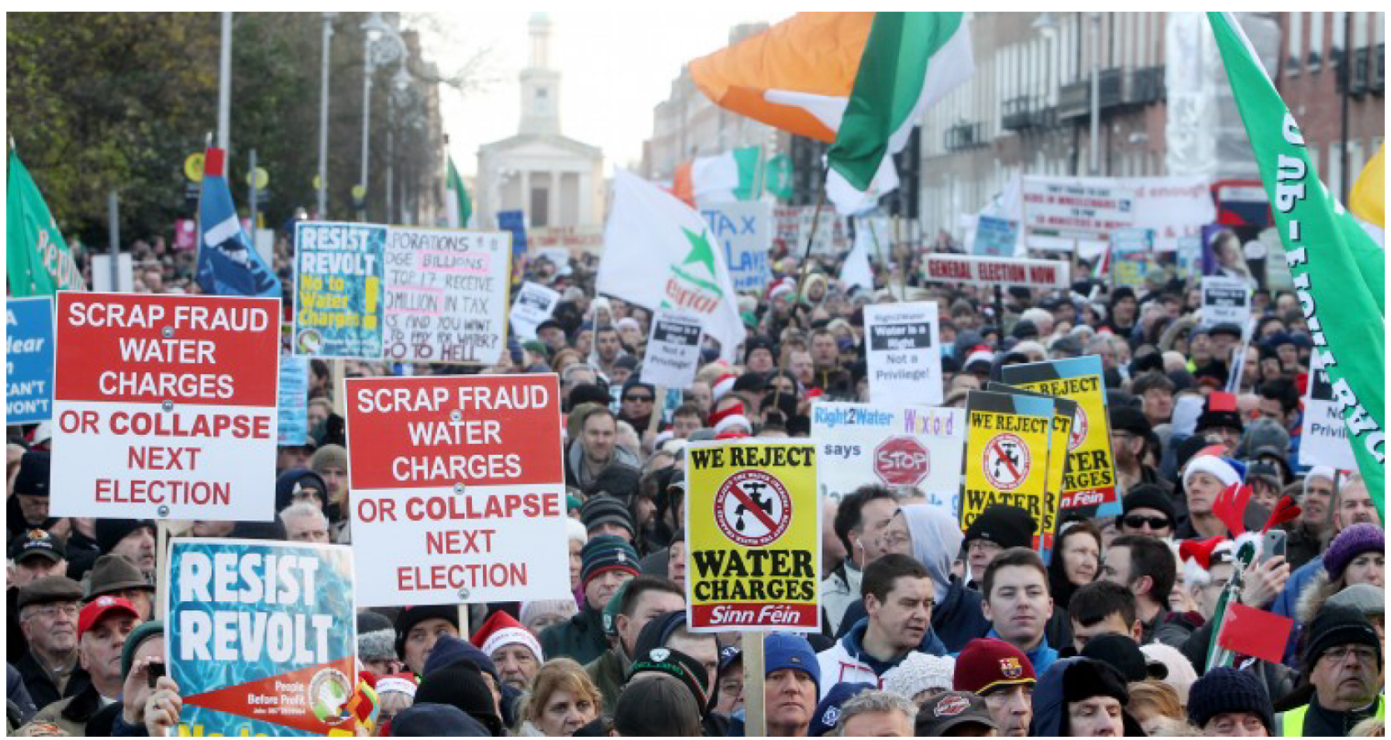

Plate 1. Performing popular sovereignty? Water Protest March in Dublin August 29th 2015.

Source: Author's own

we have sought to supplement existing intellectual resources by exploring the nexus of scarcity, alienation, and anarchic protest found in Jean-Paul Sartre's Critique of Dialectical Reason, and the relationship between precarity, public assembly, and popular sovereignty envisaged in Judith Butler's Notes Toward a Performative Theory of Assembly. Our central conclusion is that in many ways Ireland's water protest movement embodied the highest ideals of the Sartrean fused group. Certainly it revealed the strengths and limitations of Sartrean hope. It is everyday encounters with scarcity and atomised struggle with privation Sartre claims, that birth groups in fusion, the motor force of history. Through public assembly Butler argues, protests perform popular sovereignty and place in doubt the authority of representative politics; here the Sartrean group in fusion secures its potency. But groups in fusion, Sartre warns, inevitably ossify into oppressive institutions. Sartre's warning is especially prophetic given the proclivity of the politics of the left behinds to become a politics of retrenchment and exclusion, and the disposition of some Right and Left populisms to degenerate into crippling bureaucracies, nationalist spasms, and even pre-Fascist fraternities. What makes the Irish case fascinating and worthy of scrutiny is the fact that protest never ossified and totalised into an oppressive or regressive form of fraternity terrorism.

When set into international relief, it is clear that Ireland's protests betrayed a number of unique characteristics which enabled them to retain their plasticity, elasticity, and indeterminacy. First, protests were not orchestrated by established actors and infact owe their existence to a vacuum left by the mainstream centre-right's incorporation of the formal political machinery into the austerity programme and the inaction and impotence of the traditional activist base. Secondly, central to the Irish story is the ways in which everyday encounters with austerity stimulated a new tradition of autonomous and dispersed 'first time' grass roots activist and community led protests. Third, the Irish protests erupted late in the day, in part because the uneven distribution of precarity and scarcity sabotaged the capacity of community groups to unite and promoted seriality over sociality; in the end it took the universal problem of water charges to trigger collective action. Fourthly, community groups, small trade unions, and minority antiausterity political parties and independents acted as third parties and gathered tributaries of protest but they were never willing or able to achieve anything other than a light incubation of group praxis. Fifthly, atomised protests agglomerated and scaled into powerful currents of protest in part through the spatial practice of public assembly which always remained in flux and beyond the control of any organising constituency; indeed they were progenitors of novelty and emergence. Finally, we have shown that protest exacted a heavy if in the end short lived toll on the political establishment, causing panic over the latter's right to custody over democracy. It was success which sustained belief that the anarchic formula was working.

Whilst not drifting into a fossilised bureaucracy or oppressive fraternity, arguably Ireland's Right2Change movement is evaporating without a lasting legacy. Neoliberalism redux implies that Ireland's moment of fusion is petrifying and that seriality is once again triumphing over mutuality and reciprocity. As the excitement of the protest ebbs, the country is yielding to a new passive submissiveness, a new plurality of solitudes. But the reassertion of neoliberalism is an active and contingent accomplishment and remains vulnerable as a politico-institutional project over the longue durée. There will be no easy reassertion of Celtic Tiger 2.0. A watchful eye on the unfolding of a dialectic between seriality and fusion in Ireland is merited. In a second Irish Republic, the key question will be, if not the neoliberal juggernaut then what? (Murphy, 2016). And to the extent that Ireland can provide a compelling alternative, its politico-institutional future might carry lessons for the wider transmogrification and eclipsing of the neoliberal order. Through the water movement, Ireland birthed a historically novel and entirely unexpected group-in-fusion, energising a species of Left populism which may in time prove to have constituted the first stirrings of a new social democratic project.

\section{References}

Arampatzi, A., 2017. Contentious spatialities in an era of austerity: Everyday politics and 'struggle communities' in Athens Greece. Political Geography 60, 47-56.

Boyle, M., 2005. Sartre's circular dialectic and the empires of abstract space: a history of space and place in Ballymun, Dublin. Ann. Assoc. Am. Geogr. 95, 181-201.

Boyle, M., Kobayashi, A., 2011. Metropolitan Anxieties: a critical appraisal of Sartre's theory of colonialism. Trans. Inst. Br. Geographers Ns 42, 158-177.

Boyle, M., Kobayashi, A., 2015. In the face of epistemic injustices?: On the meaning of people-led war crimes tribunals. Environ. Planning D 33, 697-713.

Boyle, M., Wood, P., 2017. 'On maitre'd's, Trojan horses and aftershocks: Neoliberalism Redux in Ireland after the crash'. Irish Geography 50.

Butler, J., 2004. Precarious Life: The Powers of Mourning and Violence. Verso, New York. Butler, J., 2009. Frames of War: When is Life Grieveable? Verso, London.

Butler, J., Athanasiou, A., 2013. Dispossession: the Performative in the Political. Polity Press, Cambridge, UK, Malden, Massachusetts.

Butler, J., 2015. Notes Toward A Performative Theory of Assembly. Harvard University Press, Cambridge, Massachusetts.

Coulter, C., Nagle, A. (Eds.), 2015. Ireland Under Austerity: Neoliberal Crisis, Neoliberal Solutions. Oxford University Press, Oxford.

Davies, J.S., Blanco, I., 2017. Austerity urbanism: Patterns of neo-liberalisation and 
resistance in six cities of Spain and the UK. Environ. Planning A 49, 1517-1536. Della Porta, D, 2015. Social Movements in Times of Austerity. Polity Press, Cambridge. Featherstone, D., 2012. Articulating 'new partitions of the sensible'. Political Geography 31, 324-333.

Fraser, A., Murphy, E., Kelly, S., 2013. Deepening neoliberalism via austerity and 'reform': The case of Ireland. Hum. Geography 6, 38-53.

Gerbaudo, P., 2017. The indignant citizen: anti-austerity movements in southern Europe and the anti-oligarchic reclaiming of citizenship. Social Movement Stud. 16, 36-50.

Halvorsen, S., 2017. Spatial dialectics and the geography of social movements: the case of Occupy London. Trans. Inst. Br. Geographers 42, 445-457.

Hearne, R., 2014. Creating utopia through real struggle: lessons from practical experiences of symbiotic strategies for transformation in austerity Ireland. Irish J. Sociol. $21,102-118$.

Hearne, R., 2015a. Ireland's water war. Interface 7 (1), 309-321.

Hearne, R., 2015. The Irish water war, austerity and the 'Risen people' An analysis of participant opinions, social and political impacts and transformative potential of the Irish anti water-charges movement (Department of Geography, Maynooth University)

Kearns, G., Meridith, D., Morrissey, J. (Eds.), 2014. Spatial Justice and the Irish Crisis. Royal Irish Academy, Dublin.

Kitchin, R., O'Callaghan, C., Boyle, M., Gleeson, J., Keaveney, K., 2012. Placing neoliberalism: the rise and fall of Ireland's Celtic Tiger. Environ. Planning A 44 (6), 1302-1326.

Kinsella, S., 2012. Is Ireland really the role model for austerity? Camb. J. Econ. 36 (1), 223-235.

Kobayashi, A., Boyle, M., 2014. Colonizing colonized: Sartre and Fanon. In: Bakan, A., Dua, E. (Eds.), Theorizing Anti-racism: Rethinking the Tensions Between Marxism and Critical Race Theory. University of Toronto Press, Toronto, pp. 184-203.

Mercille, J., Murphy, E., 2015. Deepening Neoliberalism, Austerity, and Crisis: Europe's Treasure Ireland. Palgrave Macmillan, London.

Miller, B., 2016. Spaces of Contention: Spatialities and Social Movements. Routledge, London.

McCabe, C., 2013. Sins of the Father: Tracing the Decisions that Shaped the Irish Economy. The History Press, Gloucestershire.

Murphy, M.P., 2016. What do we need for a Second Republic? High energy democracy and a triple movement. Études irlandaises 41-2, 33-50.

Nicholls, W., 2009. Place, networks, space: theorising the geographies of social movements. Trans. Inst. Br. Geographers 34, 78-93.

Nolan, L.J., Featherstone, D., 2015. Contentious politics in austere times. Geography Compass 9, 351-361.

O'Callaghan, C., Boyle, M., Kitchin, R., 2014. Post-politics, crisis, and Ireland's ghost estates. Political Geography 42, 121-133.

O'Callaghan, C., Kelly, S., Boyle, M., Kitchin, R., 2015. Topologies and topographies of Ireland's neoliberal crisis. Space Polity 19 (1), 31-46.

O'Connor, N., Staunton, C., 2015. Cherishing all Equally: Economic Inequality in Ireland. Tasc, Dublin.

O'Connor, F., 2017. The presence and absence of protest in austerity Ireland. In: DellaPorte, D., Andretta, M., Fernandez, T. (Eds.), Late Neoliberalism and its Discontents in the Economic Crisis: Comparing Social Movements in the European Periphery. Springer International Publishing, Rotterdam, pp. 65-98.

O'Riain, S., 2014. The Rise and Fall of Ireland's Celtic Tiger: Liberalism, Boom and Bust. Cambridge University Press, Cambridge.

Regan, A., 2016. Debunking myths: Why austerity and structural reforms have had little to do with Ireland's economic recovery (LSE European Politics and Policy (EUROPP) Blog).

Roche, W.K., O'Connell, P.J., Prothero, A., 2017. Austerity and Recovery in Ireland Europe's Poster Child and the Great Recession. Oxford University Press, Oxford.

Routledge, P., 2003. Convergence space: process geographies of grassroots globalization networks. Trans. Inst. Br. Geographers 28, 333-349.

Routledge, R., 2015. Territorialising movement: the politics of land occupation in Bangladesh. Trans. Inst. Br. Geographers 40, 445-463.

Sartre, J.-P., 1943. Being and Nothingness: An Essay on Phenomenological Ontology. Routledge, London.

Sartre, J.-P., 1976. Critique of Dialectical Reason Volume 1: Theory of Practical Ensembles. New Left Books, London.

Sartre, J.-P., 1991. Critique of Dialectical Reason, Volume 2: The Intelligibility of History. Verso, London, Chicago, IL.

Sartre, J.-P., Levy, B., 1995. Hope Now: The 1980 Interviews Translated by A van den Hoven. The University of Chicago Press, Chicago, IL. 